Bull. Chem. Soc. Ethiop. 2018, 32(3), 451-458.

ISSN 1011-3924

(c) 2018 Chemical Society of Ethiopia and The Authors

Printed in Ethiopia

DOI: https://dx.doi.org/10.4314/bcse.v32i3.4

\title{
SYNTHESIS AND EVALUATION OF THE ANTIMICROBIAL POTENTIALS OF COBALT DOPED- AND MAGNESIUM FERRITE SPINEL NANOPARTICLES
}

\author{
C.O. Ehi-Eromosele ${ }^{1 *}$, J.A.O. Olugbuyiro ${ }^{1 *}$, O.S. Taiwo ${ }^{2}$, O.A. Bamgboye ${ }^{1}$ and C.E. Ango ${ }^{1}$ \\ ${ }^{1}$ Department of Chemistry, Covenant University, PMB 1023, Ota, Nigeria \\ ${ }^{2}$ Department of Biological Sciences, Covenant University, PMB 1023, Ota, Nigeria
}

(Received August 12, 2017; Revised September 16, 2018; Accepted October 2, 2018)

\begin{abstract}
The high incidence of infectious disease and increase in the incidence of antibiotic resistance has led to the exploitation of inorganic nanoparticles as novel antimicrobial agents owing to their unique physical and chemical properties. This study reports the synthesis and antibacterial activity of magnesium ferrite $\left(\mathrm{MgFe}_{2} \mathrm{O}_{4}\right)$ and cobalt doped magnesium ferrite $\left(\mathrm{Co}_{0.8} \mathrm{Mg}_{0.2} \mathrm{Fe}_{2} \mathrm{O}_{4}\right)$ spinel nanoparticles (NPs). The NPs were synthesized using the low temperature combustion synthesis. X-ray diffraction (XRD), scanning electron microscope (SEM) and energy dispersive absorption spectroscopy (EDAX) were used to characterize the synthesized NPs. The synthesized NPs exhibited good antibacterial properties against Pseudomonas aeruginosa, Escherichia coli, Staphylococcus aureus and Serratia marcescens. None of the nanoparticles induced any microbial inhibition against Micrococcus varians, Aspergillus flavus, Bacillus substilis and Candida. albicans. $\mathrm{Co}_{0.8} \mathrm{Mg}_{0.2} \mathrm{Fe}_{2} \mathrm{O}_{4} \mathrm{NPs}$ gave better antibacterial activity with a zone of inhibition of $>20 \mathrm{~mm}$ against Staphylococcus aureus and Escherichia coli compared to $\mathrm{MgFe}_{2} \mathrm{O}_{4} \mathrm{NPs}$. The minimum inhibitory concentration of $\mathrm{Co}_{0.8} \mathrm{Mg}_{0.2} \mathrm{Fe}_{2} \mathrm{O}_{4} \mathrm{NPs}$ against Escherichia coli and Staphylococcus aureus was $2500 \mu \mathrm{g} / \mathrm{mL}$ and $1250 \mu \mathrm{g} / \mathrm{mL}$, respectively. The relatively high antibacterial effect exhibited by $\mathrm{Co}_{0.8} \mathrm{Mg}_{0.2} \mathrm{Fe}_{2} \mathrm{O}_{4}$ nanoparticles on Escherichia coli and Staphylococcus aureus suggests its potentials in the treatment of infections commonly associated with these microorganisms.
\end{abstract}

KEY WORDS: Magnesium ferrite, Nanoparticles, Antibacterial activity, Combustion synthesis, Infectious disease

\section{INTRODUCTION}

Despite intensive research efforts on chemotherapeutic antimicrobial agents over the last few decades, the incidence of infectious disease, antibiotic resistance and the associated morbidity and mortality still remains high $[1,2]$. Naturally, this has led to the search for new antimicrobial agents. In the past decade, nanobiotechnology has attracted a lot of attention because of its therapeutic potentials in various biomedical applications. This therapeutic potentials of nanoparticles in biomedical applications stems from their unique physical and chemical properties such as nanometer size, greater surface area to volume ratio, greater bioavailability, ability to interact on cell surface and cross cell membrane. These are the properties that are being exploited in nanobiotechnology to offset the inherent limitations associated with conventional/traditional therapeutic and diagnostic agents [3].

Several inorganic nanoparticles have been exploited and investigated as potential antimicrobial agents with well documented antimicrobial activity. From ancient times, inorganic silver salts have been effectively used as antimicrobials. The recalcitrant issue of antibiotic resistance microorganisms has elicited research in exploiting silver nanoparticles as a more effective antimicrobial agent [4-6]. The antimicrobial potentials of silver nanoparticles have led to the surge in studies and exploitation of other inorganic NPs as antimicrobial agents. Different reports have recorded considerable antibacterial activity for many metal oxide NPs such as $\mathrm{CuO}$, $\mathrm{MgO}, \mathrm{ZnO}, \mathrm{TiO}_{2}$, etc. [7-10]. These metal oxides exhibit metallic, insulator and semiconductor properties. The semiconductors are further classified into i-, n- and p-types. While the n-types are electron excess semiconductor with free electrons as charge carriers the p-types are electron

*Corresponding author. E-mail: cyril.ehi-eromosele@covenantuniversity.edu.ng

This work is licensed under the Creative Commons Attribution 4.0 International License 
deficient with a cation deficient oxide. It is these electronic structural features that confer characteristic chemical and physical properties to these metal oxide NPs by which they interact with biological systems [11, 12]. Also, although transition metal oxides like the spinel ferrites have typically been exploited as technological materials; their biomedical applications have being attracting lots of attention recently. The very promising potentials of spinel ferrites, like other magnetic nanoparticles, in biomedical applications are due to their biocompatibility, ease of synthesis, ability to be manipulated by a magnet, low cost and their chemical and thermal stability [13].

Spinel ferrites are metal oxides with the common formula $\mathrm{MFe}_{2} \mathrm{O}_{4}$ (where $\mathrm{M}$ can be a divalent metal, e.g. $\mathrm{Ni}, \mathrm{Zn}, \mathrm{Mn}, \mathrm{Co}, \mathrm{Mg}, \mathrm{Cu}$, etc.). The interests in spinel ferrites are because of their well-documented electronic, magnetic and optical properties. Amongst the spinel ferrite families, magnesium ferrite $\left(\mathrm{MgFe}_{2} \mathrm{O}_{4}\right)$ is a soft magnetic n-type semi-conducting material which finds applications in the fields of heterogeneous catalysis, adsorption, sensors and magnetic technologies [14]. Magnesium ferrite is one of the most important ferrites with a lower magnetic property compared to most other spinel ferrites. However, there is paucity of literature using such magnetic nanoparticles for biological and medical purposes. There are some reports on the antimicrobial activity of many spinel ferrites $[15,16]$ which has being eliciting much interest for their antimicrobial potentials since their other biomedical applications were brought to fore. Magnesium ferrites nanoparticles have been used as potential anti-cancer agents and are used in many biological applications [17] but their antibacterial property has not been reported. Also, there are reports that transition metal doping of spinel ferrites can enhance their antibacterial property $[18,19]$. Therefore, the objective of this study is to synthesize and evaluate the antibacterial activity of magnesium ferrite $\left(\mathrm{MgFe}_{2} \mathrm{O}_{4}\right)$ and cobalt doped magnesium ferrite $\left(\mathrm{Co}_{0.8} \mathrm{Mg}_{0.2} \mathrm{Fe}_{2} \mathrm{O}_{4}\right)$ spinel nanoparticles.

\section{EXPERIMENTAL}

\section{Materials}

All chemical reagents - $\mathrm{Mg}\left(\mathrm{NO}_{3}\right)_{2} \cdot 6 \mathrm{H}_{2} \mathrm{O}, \mathrm{Co}\left(\mathrm{NO}_{3}\right)_{2} \cdot 6 \mathrm{H}_{2} \mathrm{O}, \mathrm{Fe}\left(\mathrm{NO}_{3}\right)_{3} \cdot 9 \mathrm{H}_{2} \mathrm{O}$, glycine $\left(\mathrm{C}_{2} \mathrm{H}_{5} \mathrm{NO}_{2}\right)$, urea $\left(\mathrm{CH}_{4} \mathrm{~N}_{2} \mathrm{O}\right)$ and ammonium acetate $\left(\mathrm{CH}_{3} \mathrm{COONH}_{4}\right)$ were of analytical grade and used as received without further purification.

Synthesis

Nanoparticles of $\mathrm{MgFe}_{2} \mathrm{O}_{4}$ and $\mathrm{Co}_{0.8} \mathrm{Mg}_{0.2} \mathrm{Fe}_{2} \mathrm{O}_{4}$ ferrite were synthesized using the low temperature combustion synthesis technique following the methods in [14] and [20], respectively. In a typical synthesis procedure, stoichiometric amounts of the appropriate metal nitrates and fuel were dissolved in about $20 \mathrm{~mL}$ of distilled water in a glass beaker which was heated to $80{ }^{\circ} \mathrm{C}$ to form a viscous gel with magnetic stirring. The beaker was transferred to a hot plate pre-heated to about $300{ }^{\circ} \mathrm{C}$. The possible combustion reaction, under equilibrium condition, for the synthesis of $\mathrm{MgFe}_{2} \mathrm{O}_{4}$ and $\mathrm{Co}_{0.8} \mathrm{Mg}_{0.2} \mathrm{Fe}_{2} \mathrm{O}_{4}$ nanoferrites can be expressed by Eqs. 1 and 2, respectively.

$\mathrm{Mg}\left(\mathrm{NO}_{3}\right)_{2} \cdot 6 \mathrm{H}_{2} \mathrm{O}(\mathrm{s})+2 \mathrm{Fe}\left(\mathrm{NO}_{3}\right)_{3} \cdot 9 \mathrm{H}_{2} \mathrm{O}(\mathrm{s})+4.44 \mathrm{CH}_{2} \mathrm{NH}_{2} \mathrm{COOH}(\mathrm{s})+(9.99-10) \mathrm{O}_{2}(\mathrm{~g}) \rightarrow$ $\mathbf{M g F e}_{2} \mathbf{O}_{4}(\mathbf{s})+8.88 \mathrm{CO}_{2}(\mathrm{~g}) \uparrow+(4+2.22) \mathrm{N}_{2}(\mathrm{~g}) \uparrow+(24+11.1) \mathrm{H}_{2} \mathrm{O}(\mathrm{g}) \uparrow$

$0.8 \mathrm{Co}\left(\mathrm{NO}_{3}\right)_{2} \cdot 6 \mathrm{H}_{2} \mathrm{O}(\mathrm{s})+0.2 \mathrm{Mg}\left(\mathrm{NO}_{3}\right)_{2} \cdot 6 \mathrm{H}_{2} \mathrm{O}(\mathrm{s})+2 \mathrm{Fe}\left(\mathrm{NO}_{3}\right)_{3} \cdot 9 \mathrm{H}_{2} \mathrm{O}(\mathrm{s})+4.44 \mathrm{C}_{2} \mathrm{H}_{5} \mathrm{NO}_{2}(\mathrm{~s})+$ $(9.99-10) \mathrm{O}_{2} \rightarrow \mathbf{C o}_{0.8} \mathbf{M g}_{0.2} \mathbf{F e}_{2} \mathbf{O}_{4}(\mathrm{~s})+8.88 \mathrm{CO}_{2}(\mathrm{~g}) \uparrow+(24+11.1) \mathrm{H}_{2} \mathrm{O}(\mathrm{g}) \uparrow+(4+2.22) \mathrm{N}_{2}(\mathrm{~g}) \uparrow$

The resulting auto-combusted products which were sintered for $2 \mathrm{~h}$ were investigated for their antibacterial activity against multidrug resistant organisms. 


\section{Characterisation of synthesised ferrite nanoparticles}

XRD was used to identify the structure and phase of the nanoparticles. The X-ray diffractograms of the annealed powders were recorded at room temperature using a D8 Advance Bruker diffractometer with $\mathrm{Cu}-\mathrm{K} \alpha$ radiation source at $\lambda=0.15406 \mathrm{~nm}$ in the $2 \theta$ scan range between $10^{\circ}$ and $80^{\circ}$ at $40 \mathrm{kV}$ and $40 \mathrm{~mA}$ with a scan step of $0.02^{\circ}$. The X-ray line broadening diffraction peak (311) was employed to calculate the mean crystallite size (D) of the NPs using the well-known Debye-Scherrer relation:

$D=\frac{0.9 \lambda}{\beta \operatorname{Cos} \theta}$

where $\beta$ is equal to the spectral breadth of the line broadening of the (311) peak measured at half of the height of the peak, $\theta$ is the Bragg angle and $\lambda$ is the radiation wavelength of $\mathrm{X}$-ray used. The surface morphological images and elemental composition of the synthesized NPs were obtained using SEM Ametek model XL30 Lab 6.

\section{Antimicrobial study}

The bacterial cultures of Staphylococcus aureus, Escherichia coli, Pseudomonas aeruginosa, Serratia marcescens, Micrococcus varians, Bacillus substilis and fungal strains of Candida albicans and Aspergillus flavus were obtained from the Department of Biological Sciences, Applied Biology and Biotechnology Unit, Covenant University, Nigeria. The modified antimicrobial test procedure [21] was followed. The bacteria were cultured in nutrient broth and were allowed to grow in an incubator at $37{ }^{\circ} \mathrm{C}$ for $24 \mathrm{~h}$ and used for further experiments. The fungi were maintained in slants of SDA. Microbial suspensions of $0.5 \%$ McFarland standard obtained from bacterial cultures developed on solid media were used. The nanoparticles were suspended in dimethyl sulfoxide (DMSO) to prepare a stock solution of $20 \mathrm{mg} / \mathrm{mL}$ concentration. Gingasu et al. [22] have shown that DMSO does not show any activity against the test organisms except for Escherichia coli where partial inhibition of its growth was recorded. Agar well diffusion method was used for the antibacterial activity determination. The agar plates were inoculated in an overnight culture of each bacteria isolate in sterile petri-dishes. Holes were drilled in the agar layer of each plate using a $9 \mathrm{~mm}$ diameter standard sterile corkborer. Equal volumes of the ferrite compounds (NPs) were introduced in the holes using a micropipette and allowed to diffuse for one hour at room temperature. Gentamicin and Tioconazole were used as reference drugs for bacteria and fungi, respectively, at the concentration of $10 \mu \mathrm{g} / \mathrm{mL}$. The plates were incubated at $37{ }^{\circ} \mathrm{C}$ for $24 \mathrm{~h}$ for the bacteria, the plates for fungi were incubated at $25^{\circ} \mathrm{C}$ for 3 days. Since $\mathrm{Co}_{0.8} \mathrm{Mg}_{0.2} \mathrm{Fe}_{2} \mathrm{O}_{4}$ nanoparticles showed very high inhibitory potentials against the growth of Staphylococcus aureus and Escherichia coli, the minimum inhibitory concentration (MIC) of the nanoparticle was carried out. Two-fold serial dilutions of the test compound were made to obtain the concentrations of 5000, 2500, 1250,625 and $312.5 \mu \mathrm{g} / \mathrm{mL}$. With a micropipette, $0.1 \mathrm{~mL}$ of the standard inoculums of the micro-organisms in the normal saline was then inoculated into different concentration in the test tubes and the test tubes were incubated at $37{ }^{\circ} \mathrm{C}$ for 24 hours. The minimum inhibitory concentration was observed and the values were recorded.

\section{RESULTS AND DISCUSSION}

\section{Phase analysis}

The XRD patterns of the annealed samples of $\mathrm{MgFe}_{2} \mathrm{O}_{4}$ and $\mathrm{Co}_{0.8} \mathrm{Mg}_{0.2} \mathrm{Fe}_{2} \mathrm{O}_{4}$ powders are shown in Figure 1. The XRD lines are presented with Miller indices. All the diffraction peaks confirms the formation of $\mathrm{MgFe}_{2} \mathrm{O}_{4}$ (space group Fd3m, JCPDS card no. 73-1720) and $\mathrm{Co}_{0.8} \mathrm{Mg}_{0.2} \mathrm{Fe}_{2} \mathrm{O}_{4}$ 
cubic spinel structure (space group Pn3m, JCPDS card no. 5-667). The diffractogram of the samples exhibited intense peaks which indicated that the samples had high crystallinity. It can be seen that the 111 reflection is missing in the spectra of $\mathrm{MgFe}_{2} \mathrm{O}_{4}$. This might be due to the absence of $\mathrm{Co}^{2+}$ ion in $\mathrm{MgFe}_{2} \mathrm{O}_{4}$ sample but present in both the tetrahedral and octahedral sites of $\mathrm{Co}_{0.8} \mathrm{Mg}_{0.2} \mathrm{Fe}_{2} \mathrm{O}_{4}$ spinel. It is well known that $\mathrm{Co}^{2+}$ has a much higher scattering factor than the $\mathrm{Mg}^{2+}$. The formation of $\mathrm{MgFe}_{2} \mathrm{O}_{4}$ and $\mathrm{Co}_{0.8} \mathrm{Mg}_{0.2} \mathrm{Fe}_{2} \mathrm{O}_{4}$ spinel ferrites is confirmed by the XRD patterns. The crystallite sizes of the samples were found to be $55 \mathrm{~nm}$ and $53 \mathrm{~nm}$ for $\mathrm{MgFe}_{2} \mathrm{O}_{4}$ and $\mathrm{Co}_{0.8} \mathrm{Mg}_{0.2} \mathrm{Fe}_{2} \mathrm{O}_{4}$ spinel ferrites, respectively.
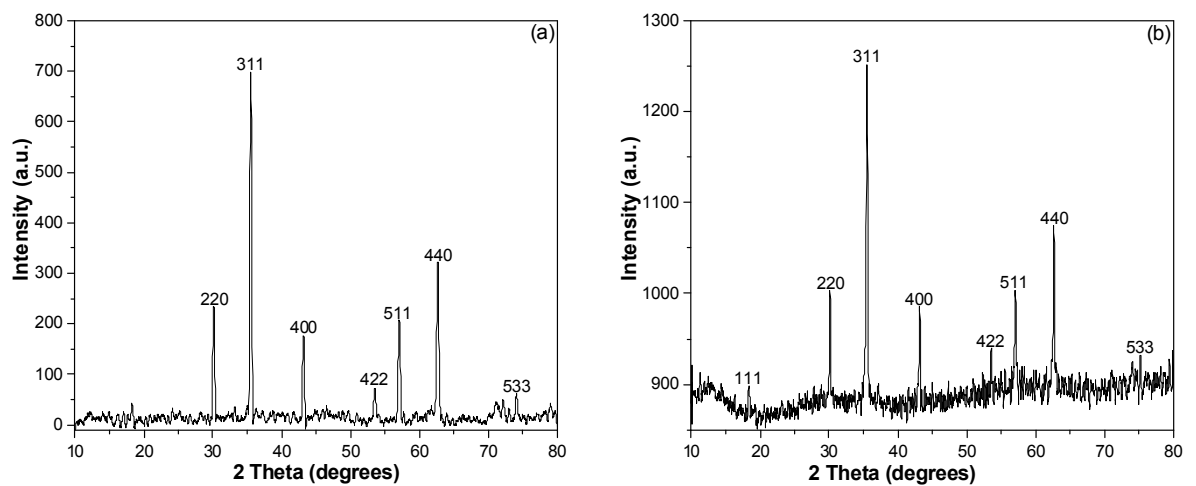

Figure 1. X-ray diffraction patterns of spinel ferrites (a) $\mathrm{MgFe}_{2} \mathrm{O}_{4}$ and (b) $\mathrm{Co}_{0.8} \mathrm{Mg}_{0.2} \mathrm{Fe}_{2} \mathrm{O}_{4}$.

\section{Morphological and chemical composition analysis}

To study the microstructure of the samples, the SEM images of $\mathrm{MgFe}_{2} \mathrm{O}_{4}$ and $\mathrm{Co}_{0.8} \mathrm{Mg}_{0.2} \mathrm{Fe}_{2} \mathrm{O}_{4}$ powders were obtained and are shown in Figure 2. The samples showed the formation of multigrain agglomerates which consists of very fine crystallites since they show tendency to form agglomerates [23]. Magnetic nanoparticles are known to form agglomerates not only because of their inherent magnetic properties but because of their high surface energy hence they tend to agglomerate to diminish this energy. The particles had a pseudo-spherical shape. There was more uniformity in the crystalline nanoparticles of $\mathrm{Co}_{0.8} \mathrm{Mg}_{0.2} \mathrm{Fe}_{2} \mathrm{O}_{4}$ than $\mathrm{MgFe}_{2} \mathrm{O}_{4}$ nanoparticles.
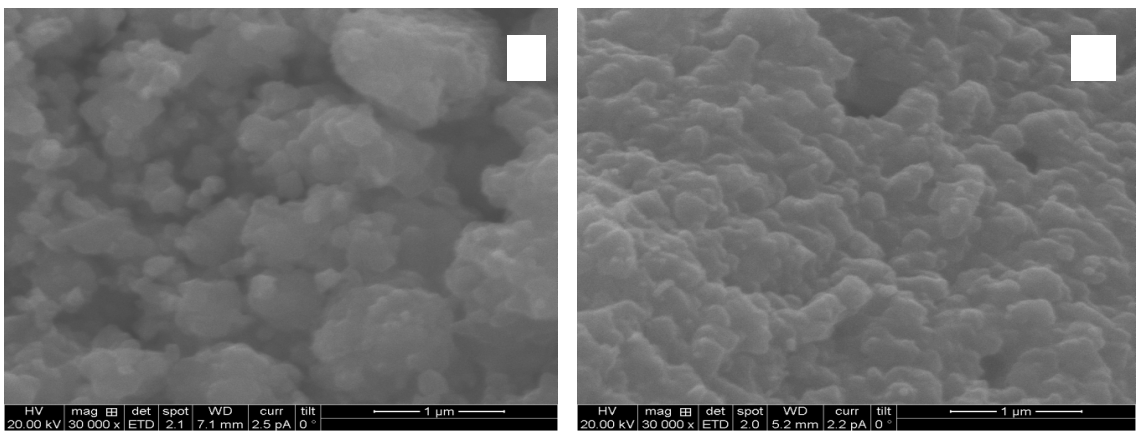

Figure 2. SEM images of spinel ferrites (a) $\mathrm{MgFe}_{2} \mathrm{O}_{4}$ and (b) $\mathrm{Co}_{0.8} \mathrm{Mg}_{0.2} \mathrm{Fe}_{2} \mathrm{O}_{4}$. 

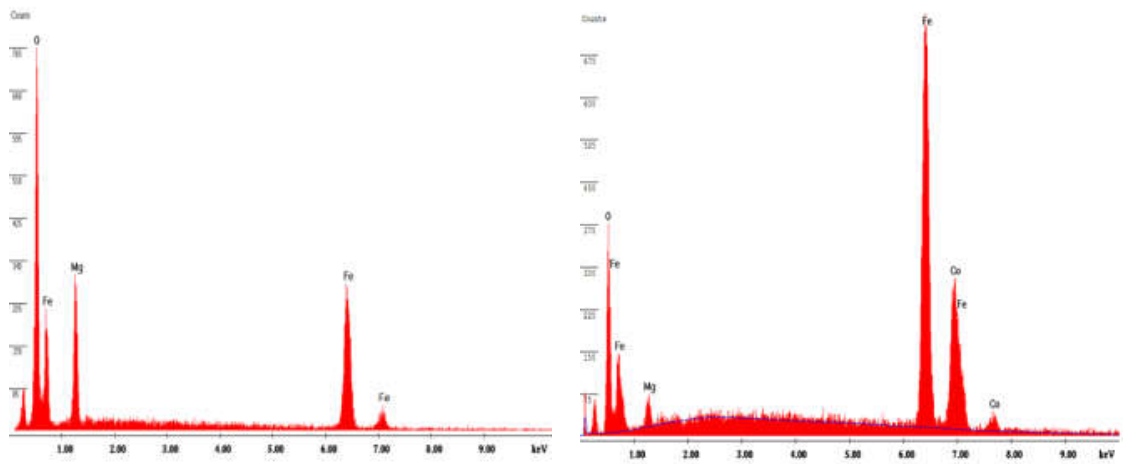

Figure 3. EDAX spectra of spinel ferrites (a) $\mathrm{MgFe}_{2} \mathrm{O}_{4}$ and (b) $\mathrm{Co}_{0.8} \mathrm{Mg}_{0.2} \mathrm{Fe}_{2} \mathrm{O}_{4}$.

The EDAX analysis was used to investigate the chemical composition of the nanoparticles and it is shown in Figure 3. The results show that the nanoparticles did not contain any impurity elements and the compositional molar ratio of $\mathrm{Mg}$ to $\mathrm{Fe}$ in $\mathrm{MgFe}_{2} \mathrm{O}_{4}$ and $\mathrm{Co}$ and $\mathrm{Mg}$ to $\mathrm{Fe}$ was close to 0.5 .

\section{Antimicrobial studies}

Reports on the antimicrobial activity of $\mathrm{MgFe}_{2} \mathrm{O}_{4}$ and $\mathrm{Co}_{0.8} \mathrm{Mg}_{0.2} \mathrm{Fe}_{2} \mathrm{O}_{4}$ nanoparticle are scarce in literature. In this work, the antimicrobial activities of the synthesized nanoparticles were tested against gram-positive and gram-negative bacteria and also against fungi strains. The antimicrobial effects of the nanoparticles were qualitatively measured by performing agar diffusion test against all the test microorganisms. The results of zones of inhibition are given in Figure 4 and the zones of inhibition are shown in Table 1 . The absence of microbial growth around the nanoparticles is an indirect measure of the ability of the nanoparticle to inhibit the growth [24]. The results reveal that the nanoparticles showed activity against some of the bacteria strains but gave no activity against the fungal strain. $\mathrm{MgFe}_{2} \mathrm{O}_{4}$ nanoparticles showed antibacterial effect against $S$. aureus, E. coli, P. aeruginosa and $S$. marcescens while $\mathrm{Co}_{0.8} \mathrm{Mg}_{0.2} \mathrm{Fe}_{2} \mathrm{O}_{4}$ nanoparticle showed antibacterial effect against $S$. aureus, E. coli and $S$. marcescens. None of the nanoparticles induced any microbial inhibition against $M$. varians, $A$. flavus, B. substilis and C. albicans. It is well known that the antibacterial activities of nanoparticles depend on their physicochemical properties and type of bacteria [25]. $\mathrm{Co}_{0.8} \mathrm{Mg}_{0.2} \mathrm{Fe}_{2} \mathrm{O}_{4}$ nanoparticles gave higher bactericidal activity against gram-positive cocci $(S$. aureus) and gram-negative bacteria (E. coli) compared to $\mathrm{MgFe}_{2} \mathrm{O}_{4}$ nanoparticles with zones of inhibition $>20 \mathrm{~mm}$. The zones of inhibition recorded for these bacteria strains ( $S$. aureus and $E$. coli) by $\mathrm{Co}_{0.8} \mathrm{Mg}_{0.2} \mathrm{Fe}_{2} \mathrm{O}_{4}$ nanoparticles were higher than the zone of inhibition for the standard antibiotic (gentamycin) used and also the zone of inhibition found in literature for these organisms by other nanoparticle based antibiotics [22,24,26]. S. aureus and E. coli are a major cause of various humans and animals infections [27]. These results show that $\mathrm{Co}_{0.8} \mathrm{Mg}_{0.2} \mathrm{Fe}_{2} \mathrm{O}_{4}$ nanoparticles can find application as antibiotics against these microbes. The mechanism of nanoparticles in their bactericidal activity is still speculative and not fully understood [28]. Multiple mechanisms of the antibacterial action of nanoparticles have been proposed. Aside the large surface area to volume ratio of nanoparticles which results in better contact with bacterial cell; antibacterial action is generated by the induction of oxidative stress by free radical formation [25]. 
The MIC of $\mathrm{Co}_{0.8} \mathrm{Mg}_{0.2} \mathrm{Fe}_{2} \mathrm{O}_{4}$ nanoparticles at varying concentrations against $S$. aureus and E. coli was determined and the results are presented in Table 2. The results show a dose dependent bactericidal activity of the $\mathrm{Co}_{0.8} \mathrm{Mg}_{0.2} \mathrm{Fe}_{2} \mathrm{O}_{4}$ nanoparticles. $\mathrm{Co}_{0.8} \mathrm{Mg}_{0.2} \mathrm{Fe}_{2} \mathrm{O}_{4} \mathrm{NPs}$ showed MIC values at $2500 \mu \mathrm{g} / \mathrm{mL}$ and $1250 \mu \mathrm{g} / \mathrm{mL}$ against $E$. coli and $S$. aureus, respectively. This result indicates that $\mathrm{Co}_{0.8} \mathrm{Mg}_{0.2} \mathrm{Fe}_{2} \mathrm{O}_{4}$ nanoparticles have a better bactericidal effect (with a factor of two) against $S$. aureus compared to E. coli.

Table 1. Susceptibility test of $\mathrm{MgFe}_{2} \mathrm{O}_{4}$ and $\mathrm{Co}_{0.8} \mathrm{Mg}_{0.2} \mathrm{Fe}_{2} \mathrm{O}_{4}$ nanoparticles.

\begin{tabular}{|l|c|c|c|c|}
\hline \multirow{2}{*}{ Test organism } & \multicolumn{2}{|c|}{ Zone of inhibition $(\mathrm{mm})$} & & TIOC \\
\cline { 2 - 5 } & $\mathrm{MgFe}_{2} \mathrm{O}_{4}$ & $\mathrm{Co}_{0.8} \mathrm{Mg}_{0.2} \mathrm{Fe}_{2} \mathrm{O}_{4}$ & GENT & - \\
\hline Staphylococcus aureus & 15 & 23 & 18 & - \\
\hline Escherichia coli & 17 & 25 & 18 & - \\
\hline Pseudomonas aeuruginosa & 12 & 0 & 0 & - \\
\hline Bacillus substilis & 0 & 0 & 20 & - \\
\hline Serratia marcescens & 16 & 11 & 0 & - \\
\hline Micrococcus varians & 0 & 0 & 20 & 13 \\
\hline Aspergillus flavus & 0 & 0 & - & 15 \\
\hline Candida albicans & 0 & 0 & - & \\
\hline
\end{tabular}

- Nil; GENT - Gentamycin; TIOC - Tioconazole; 0 - No inhibition. Assays run @ 20 mg/mL; controls @ 10 $\mu \mathrm{g} / \mathrm{mL}$.

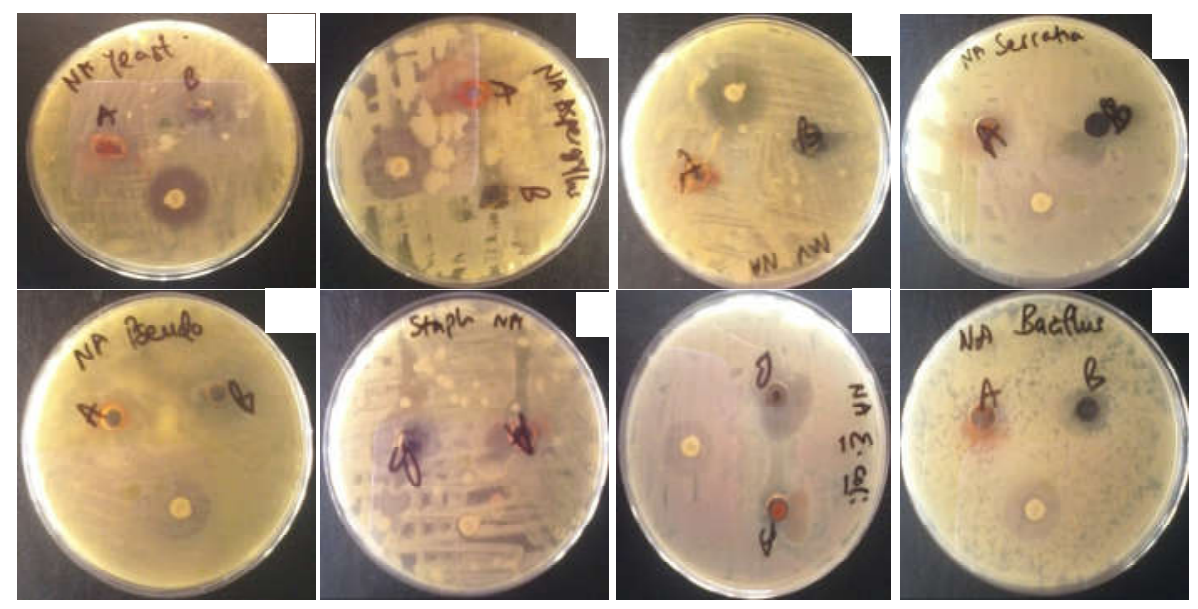

Figure 4. Petri-dishes showing the antimicrobial activity of sample $\mathrm{A}\left(\mathrm{MgFe}_{2} \mathrm{O}_{4}\right)$ and sample $\mathrm{B}$ $\left(\mathrm{Co}_{0.8} \mathrm{Mg}_{0.2} \mathrm{Fe}_{2} \mathrm{O}_{4}\right)$ against multidrug resistant microorganisms. (a) Candida albicans, (b) Aspergillus spp., (c) Micrococcus varians, (d) Serratia marcescens, (e) Pseudomonas aeruginosa, (f) Staphylococcus aureus, (g) Escherichia coli and (f) Bacillus spp.

Table 2. MIC of $\mathrm{Co}_{0.8} \mathrm{Mg}_{0.2} \mathrm{Fe}_{2} \mathrm{O}_{4}$ nanoparticle.

\begin{tabular}{|c|c|c|}
\hline $\mathrm{Co}_{0.8} \mathrm{Mg}_{0.2} \mathrm{Fe}_{2} \mathrm{O}_{4} \mathrm{NPs}(\mu \mathrm{g} / \mathrm{ml})$ & \multicolumn{2}{|c|}{ Test organism } \\
\cline { 2 - 3 } & E. coli & S. aureus \\
\hline 5000 & - & - \\
\hline 2500 & $\mathrm{O}^{+}$ & - \\
\hline 1250 & + & $\mathrm{O}^{+}$ \\
\hline 625 & ++ & + \\
\hline 312.5 & +++ & ++ \\
\hline
\end{tabular}

$\mathrm{O}^{+}$- MIC value; - - No growth; + - Light growth; ++ - Moderate growth; +++ - High growth

Bull. Chem. Soc. Ethiop. 2018, 32(3) 


\section{CONCLUSION}

The $\mathrm{MgFe}_{2} \mathrm{O}_{4}$ and $\mathrm{Co}_{0.8} \mathrm{Mg}_{0.2} \mathrm{Fe}_{2} \mathrm{O}_{4}$ spinel nanoparticles were synthesized using the low temperature combustion synthesis. The annealed samples were characterized by various techniques. XRD analysis confirmed the formation of $\mathrm{MgFe}_{2} \mathrm{O}_{4}$ and $\mathrm{Co}_{0.8} \mathrm{Mg}_{0.2} \mathrm{Fe}_{2} \mathrm{O}_{4}$ with cubic spinel structure (Fd-3m (227) space group) characteristic of these compounds. The SEM analysis showed the formation of multigrain agglomerates consisting of very fine crystallites. The samples were found not to contain any impure element and the composition was close to the nominal values. The efficacies of the bactericidal effect of these nanoparticles against a broad spectrum of bacterial strains have been reported. $\mathrm{Co}_{0.8} \mathrm{Mg}_{0.2} \mathrm{Fe}_{2} \mathrm{O}_{4}$ nanoparticles demonstrated very high antibacterial activity against gram-positive cocci ( $S$. aureus) and gram-negative bacteria $(E$. coli). It is recommended that further studies have to be carried out to determine the cytotoxicity and mechanism of action of $\mathrm{Co}_{0.8} \mathrm{Mg}_{0.2} \mathrm{Fe}_{2} \mathrm{O}_{4}$ nanoparticles on $S$. aureus and E. coli.

\section{ACKNOWLEDGEMENTS}

We acknowledge the assistance of the International Centre for Materials Science, Jawarharlal Nehru Centre for Advanced Scientific Research, Bangalore, India in the characterisation of our samples.

\section{REFERENCES}

1. Kolar, M.; Urbanek, K., Latal, T. Antibiotic selective pressure and development of bacterial resistance. Int. J. Antimicrob. Agents 2001, 17, 357-363.

2. Ravishankar, R.V.; Jamuna, B.A. Nanoparticles and Their Potential Application as Antimicrobials in Science against Microbial Pathogens: Communicating Current Research and Technological Advances, Méndez-Vilas, A. (Ed.), Formatex Research Center: Spain; 2011; pp. 197-209.

3. Zhang, L.; Gu, F.X.; Chan, J.M.; Wang, A.Z.; Langer, R.S.; Farokhzad, O.C. Nanoparticles in medicine: Therapeutic applications and developments. Clin. Pharmacol. Therap. 2008, 83, 761-769.

4. Christensen, L.; Vivekanandhan, S.; Misra, M.; Mohanty, A.K. Biosynthesis of silver nanoparticles using murraya koenigii (curry leaf): an investigation on the effect of broth concentration in reduction mechanism and particle size. Adv. Mater. Lett. 2011, 2, 429-434.

5. Saha, S.; Gupta, B.; Gupta, K.; Chaudhuri, M.G. Production of putrescine-capped stable silver nanoparticle: its characterization and antibacterial activity against multidrug-resistant bacterial strains. Appl. Nanosci. 2016, 6, 1137-1147.

6. Rai, M.K.; Deshmukh, S.D.; Ingle, A.P.; Gade, A.K. Silver nanoparticles: The powerful nanoweapon against multidrugresistant bacteria. J. Appl. Microbiol. 2012, 112, 841-852.

7. Huang, L. Controllable preparation of nano- $\mathrm{MgO}$ and investigation of its bactericidal properties. J. Inorg. Biochem. 2005, 99, 986-993.

8. Gittard, S.D.; Perfect, J.R.; Monteiro-Riviere, N.A.; Wei, W.; Jin, C.; Narayan, R.J. Assessing the antimicrobial activity of zinc oxide thin films using disk diffusion and biofilm reactor. Appl. Surf. Sci. 2009, 255, 5806-5811.

9. Ren, G.; Hu, D.; Cheng, E.W.C.; Vargas-Reus, M.A.; Reip, P.; Allaker, R.P. Characterisation of copper oxide nanoparticles for antimicrobial applications. Int. $J$. Antimicrob.l Agents 2009, 33, 587-590.

10. Chawengkijwanich, C.; Hayata, Y. Development of $\mathrm{TiO}_{2}$ powder-coated food packaging film and its ability to inactivate Escherichia coli in vitro and in actual tests. Int. J. Food Microbiol. 2008, 123, 288-292.

11. Singh, R.; Nalwa, H.S. Medical applications of nanoparticles in biological imaging, cell labeling, antimicrobial agents, and anticancer nanodrugs. J. Biomed. Nanotechnol. 2011, 7, 489-503.

12. Raghunath, A.; Ekambaram, P.; Metal oxide nanoparticles as antimicrobial agents: A promise for the future. Int. J. Antimicrob. Agents 2017, 49, 137-152.

Bull. Chem. Soc. Ethiop. 2018, 32(3) 
13. Akbarzadeh, A.; Samiei, M.; Davaran, S. Magnetic nanoparticles: Preparation, physical properties, and applications in biomedicine. Nanoscale Res. Lett. 2012, 7.

14. Ehi-Eromosele, C.O.; Ita, B.I.; Iweala, E.E.J. Synthesis, microstructure and magnetic properties of nanocrystalline $\mathrm{MgFe}_{2} \mathrm{O}_{4}$ particles: Effect of mixture of fuels and sintering temperature. Sci. Sinter. 2016, 48, 221-235.

15. Venkatesan, K.; Babu, D.R.; Bai, M.P.K.; Supriya, R.; Vidya, R.; Madeswaran, S.; Anandan, P.; Arivanandhan, M.; Hayakawa, Y. Structural and magnetic properties of cobaltdoped iron oxide nanoparticles prepared by solution combustion method for biomedical applications. Int. J. Nanomed. 2015, 10, 189-198.

16. Raveendra, R.S.; Prashantha, P.A.; Prasad, B.D.; Nayaka, S.C.; Suresha, G.P.; Nagabhushana, B.M.; Nagabhushana, H.; Bhagya, N.P. Synthesis, characterization and antibacterial activity of zinc ferrite nanopowder. Int. J. Sci. Res. 2013, 1, 543-547.

17. Kanagesan, S.; Hashim, M.; Tamilselvan, S.; Alitheen, N.B.; Ismail, I.; Bahmanrokh, G. Cytotoxic effect of nanocrystalline $\mathrm{MgFe}_{2} \mathrm{O}_{4}$ particles for cancer cure. J. Nanomater. 2013, DOI: $10.1155 / 2013 / 865024$.

18. Sanpo, N.; Berndt, C.C.; Wen, C.; Wang, J. Transition metal-substituted cobalt ferrite nanoparticles for biomedical applications. Acta Biomater. 2013, 9, 5830-5837.

19. Sanpo, N.; Wang, J.; Berndt, C.C. Effect of zinc substitution on microstructure and antibacterial properties of cobalt ferrite nanopowders synthesized by sol-gel methods. Adv. Mater. Res. 2012, 535-537, 436-439.

20. Ehi-Eromosele, C.O.; Ita, B.I.; Iweala, E.E.J. Low-temperature combustion synthesis of cobalt magnesium ferrite magnetic nanoparticles: effects of fuel-to-oxidizer ratio and sintering temperature. J. Sol-Gel Sci. Technol. 2015, 76, 298-305.

21. Olugbuyiro, J.A.O.; Taiwo, O.S.; Oniha, M.I.; Olaniyi, O.T.; Obi, F.A. In vitro study of isolated compounds from the leaf of Flabellaria paniculata against Staphylococcus aureus, Pseudomonas aeuruginosa and Candida albicans. Chem. Soc. Nigeria Book Proceed. 2016.

22. Gingasu, D.; Mindru, I.; Patron, L.; Calderon-Moreno, J.M.; Mocioiu, O.C.; Preda, S.; Stanica, N.; Nita, S.; Dobre, N.; Popa, M.; Gradisteanu, G.; Chifiriuc M.C. Green synthesis methods of $\mathrm{CoFe}_{2} \mathrm{O}_{4}$ and $\mathrm{Ag}-\mathrm{CoFe}_{2} \mathrm{O}_{4}$ nanoparticles using hibiscus extracts and their antimicrobial potential. J. Nanomater. 2016. DOI: 10.1155/2016/2106756.

23. Rezlescu, N.; Popa, P.D.; Rezlescu, E.; Doroftei, C. Microstructure, characteristics of some polycrystalline oxide compounds prepared by sol-gel self-combustion way for gas sensor applications. Romanian J. Phys. 2008, 53, 545-555.

24. Sheena, X.; Harry, C.; Nimila, P.J.; Thankachan, S.; Rintu, M.S.; Mohammed, E.M. Structural and antibacterial properties of silver substituted cobalt ferrite nanoparticles. Res. J. Pharm. Biol. Chem. Sci. 2014, 5, 364-371.

25. Mohammad, J.H.; Fromm, K.M.; Ashkarran, A.A.; de Aberasturi, D.J.; de Larramendi, I.R.; Rojo, T.; Serpooshan, V.; Parak, W.J.; Mahmoudi, M. Antibacterial properties of nanoparticles. Trends Biotechnol. 2012, 30, 499-511.

26. Oluwaniyi, O.O.; Adegoke, H.I.; Adesuji, E.T.; Alabi, A.B.; Bodede, S.O.; Labulo, A.H.; Oseghale, C.O. Biosynthesis of silver nanoparticles using aqueous leaf extract of Thevetia peruviana Juss and its antimicrobial activities. Appl. Nanosci. 2016, 6, 903-912.

27. Bachir, raho G.; Abouni, B. Escherichia coli and Staphylococcus aureus most common source of infection in the battle against microbial pathogens: Basic Science, Technological Advances and Educational Programs, Méndez-Vilas, A. (Ed.), Formatex: Spain; 2015; pp. 637-648.

28. He, Y.; Ingudam, S.; Reed, S.; Gehring, A.; Strobaugh, Jr., T.P.; Irwin, P. Study on the mechanism of antibacterial action of magnesium oxide nanoparticles against foodborne pathogens. J. Nanobiotechnol. 2016, 14, 54-60. 